\title{
En norsk matriark analyserer patriarkerne
}

\author{
Kari E. Børresens opgør med katolsk teologis lære om \\ gudbilledlighed
}

\author{
Lektor, ph.d. \\ Else Marie Wiberg Pedersen, Aarhus Universitet
}

\begin{abstract}
The Norwegian matriarch, Kari E. Børresen, died in April 2016, after a fine academic career as one of the outstanding feminist theologians of her generation. This article seeks to portray her by lifting up one of the key issues of her research within gender studies: the imago Dei and the various ways this was understood in Christian antiquity and the Middle Ages. Before embarking on that, the article introduces Børresen and her work as a feminist theologian in general.
\end{abstract}

Keywords: Kari E. Børresen - Mary Daly - Elisabeth A. Johnson -feminist theology - imago Dei - androcentrism - patristics - Catholic theology - inclusivity

\section{Indledning}

Es gibt nur ein Abbild Gottes, den Menschen; und es gibt nur einen, der es vollkommen dargestellt hat: Jesus Christus. ${ }^{1}$

(Der gives kun ét afbillede af Gud, mennesket; og der gives kun én, som har fremstillet det fuldkomment: Jesus Kristus.)

Ovenstående citat er fra Catharina Halkes (1920-2011), litterat og grundlægger af hollandsk feministteologi. I 1980'erne og frem kæmpede hun sammen med den norske idéhistoriker, teolog og matriark, Kari E. Børresen (1932-2016), for at reformere den katolske kirke. Citatet illustrerer deres fælles mål, nemlig at integrere kvinder i den gudsskabte menneskehed ved - ligesom den tidligere augustinereremit, Martin Luther, godt 450 år tidligere havde gjort - at påpege, at

1. Catharina Halkes. Gott hat nicht nur starke Söhne. Grundzüge einer feministischen Theologie. Gütersloh: Mohn 1982, 38. 
kun Kristus fremstiller det fuldkomne imago Dei, mennesket. For Halkes som for Børresen var feministisk teologi en inklusiv teologi, og teologiens sprog burde være inklusivt, rettet til hele menneskeheden, ikke kun til en del af den. Her ligger en direkte brod mod traditionel katolsk, og ortodoks, antropologi og embedsteologi. Ifølge denne er nemlig kun manden så gudbilledlig, at han kan være Guds stedfortræder i kirkelige embeder, navnlig som offerpræst foran alteret.

I april i år var det fem år siden, at Kari Børresen døde. I den anledning vil forfatteren af nærværende artikel belyse aspekter af hendes arbejde inden for den feministiske teologi, hvor hun var blandt pionererne i det, vi normalt betegner feminismens anden bølge (ca. 1968-ca. 1990).

\section{Kari Børresen - fra Skt. Josefsøster til feministisk teolog}

Kari Børresen var en personlighed, og en bemærkelsesværdig én af slagsen. I en meget tidlig alder, mellem 10 og 15 år gammel, konverterede hun til det, hun selv kaldte "elitekatolicisme". I nogle få måneder omkring 18-års-alderen forsøgte hun sig som novice hos Skt. Josefsøstrene i Chambéry i Frankrig.

Børresens katolske tro kan synes at stå i skærende kontrast til hendes skarpe intellekt og vidner om en sammensat person, der ikke $ø$ nskede at følge det hegemoniske flertal. I sin nekrolog over Kari Børresen beskrev søster Anne-Lise Strøm OP, hvordan den skarpsindige forsker havde en næsten barnlig tro på forbønnens virke for et menneskes liv. ${ }^{2}$ Børresen var nemlig først og sidst en intellektuel, hvis videnskabelige arbejde satte sig spor i kønsforskningen. Her træder endnu en kontrast til hendes katolske tro frem, da hun i hele sin akademiske karriere fokuserede på at øve konstruktiv kritik af tre sammenhængende forhold: katolsk teologis androcentrisme, Vatikanets syn på kvinders position i samfundet og dets modstand mod kvindelige præster. Derfor kunne man spørge, hvorfor hun var konverteret, eller måske snarere hvorfor hun ikke senere, da hun som kønsforsker indså den katolske kirkes massive patriarkat, vendte tilbage til protestantismen.

Men Børresen tilhørte den revisionistiske feminisme, hvor man mener, at en de- og rekonstruktiv tilgang til teologien både historisk

2. Se http://www.katolsk.no/nyheter/2016/04/in-memoriam-kari-elisabeth-borresen (set 25.05.2021). Tak til Aud V. Tønnesen for hjælp med brikker til Kari Børresens biografi, især med hensyn til spørgsmålet om hendes konversion til katolicisme. 
og aktuelt vil føre til en ændring af de patriarkalske strukturer i samfund og kirke. Strukturerne skal ændres indefra, og derfor forblev Børresen katolik til forskel fra den lidt ældre amerikanske medpioner, Mary Daly (1928-2010), som var katolskfødt, men som efterhånden blev radikalfeministisk, hvor man har en essentialistisk tilgang til patriarkatet og anser det for en stedse historisk fakticitet, der ikke står til at ændre. Daly valgte at blive post-kristen på grund af den katolske kirkes misogyni og, med hendes ord, fallokratiske optagethed af Gud som mand og manden som Gud. ${ }^{3}$ For at undgå patriarkatets undertrykkelse med grobund i et guddommeligt patriarkat blev løsningen for Daly at arbejde i retning af en gudindebevægelse og således opnå ligeværd for kvinder. Måske skyldtes dette en anden forskel de to imellem: Børresen havde aldrig som Daly fastansættelse ved en katolsk læreanstalt og var måske derfor ikke udsat for samme massive sexisme. Børresen var den flersprogede kosmopolit med gæsteprofessorater ved Gregorianum i Rom og Geneve Universitet, gæsteforsker ved Aarhus Universitet, Harvard og Uppsala, samt medlem af forskningscentre i Washington, Princeton og Collegeville. I 1982 blev hun norsk statsstipendiat, i 1993 kaldet som professor II i Middelalder og Kønsstudier ved Oslo Universitet, og fra 1995 var hun medlem af Det Norske Videnskabsakademi. Ironisk nok opnåede Børresen i 2000, hvor hun kunne have valgt at gå på pension, at blive ansat som fuld professor i feministteologi ved Det Teologiske Fakultet i Oslo, skønt hun mod de da gældende bestemmelser ikke var medlem af Den Norske Kirke. ${ }^{4}$ Ministeriet, som gav tilladelsen til det ekstraordinære skridt, begrundede den med, at feministteologi jo ikke er et centralt område. Det morede den norske matriark, hvis arbejde modsagde ministeriets argument og banede vejen for, at feministteologi og kønsforskning blev integreret i fakultetets curriculum. Skønt hun altså ikke havde været fuldt anerkendt i Norges teologiske akademier på grund af sin katolske tro, så var hun fuldt anerkendt for sin kønsforskning, også i resten af Europa. Hun fik af samme grund Norsk kvindelig Teologforenings pris i 2003 og blev æresdoktor ved både Uppsalas Universitet (1992) og Islands Universitet (2011), ligesom hun var velanskrevet leder såvel som medlem af europæiske forskernetværk og -programmer.

Til forskel fra endnu en katolskfødt feministteolog, den lidt yngre og ligeledes revisionistiske feminist, Elizabeth A. Johnson (1941-) -

3. Mary Daly tog afsked med kristen tro i bogen Beyond God the Father. Toward a Philosophy of Women's Liberation. Boston: Beacon Press 1973.

4. Øyvind Norderval \& Katrine Lund Ore, "Introduction". I From Patristics to Matristics. Selected Articles on Christian Gender Models by Kari Elisabeth Børresen, red. Øyvind Norderval \& Katrine Lund Ore. 2002. XVII-XX. Rom: Herder 2002. 
Skt. Josefsøster som den purunge Børresen - blev Børresen aldrig udsat for offentlig kritik af sine publikationer fra et katolsk bispekollegium. Den ellers bredt anerkendte Johnson fik en påtale for sin bog, Quest for the Living God fra 2007. I marts 2011 afgjorde USA's katolske bispekonference, at bogen ikke læremæssigt korresponderede med "autentisk katolsk teologi". Johnson forklarede sig, men bispekonferencen konfirmerede sin bedømmelse i oktober samme år. ${ }^{5}$ Hvordan Børresen har undgået lignende kritik fra den katolske kirkes top, er uvist, for som de nævnte feministteologer angreb hun det patriarkalske hierarki. Et godt bud er, at hun nok trods alt nød en vis beskyttelse ved at være borger i en nordisk velfærdsstat og dens institutioner, og hvor den katolske kirke til gengæld ikke havde indflydelsesrige organer. Under alle omstændigheder opsummerer Elizabeth Johnson det opgør, som Børresen gennem sin forskning gav akademisk grundlag for: "All-male images of God are hierarchical images rooted in the unequal relation between women and men ... Once women no longer relate to men as patriarchal fathers, lords, and kings in society, these images become religiously inadequate. Instead of evoking the reality of God, they block it."'

For den revisionistiske Børresen drejer en feministisk teologi sig om to sagforhold, der hører uløseligt sammen. Dels må den afdække den patriarkalsk-hierarkiske tænkning som inadækvat og i modstrid med Guds virkelighed. Børresen har taget sine kampe med det hierarkiske patriarkat både i og uden for Rom. Eftersom det mandlige hierarki er begrundet i en énsidigt maskulin tolkning såvel af gudsbilledet (eller gudsbegrebet) som af menneskets gudbilledlighed (imago Dei), var det disse to temaer, Børresen sagligt koncentrerede en del af sin forskning om. Hun påviste, hvordan den patriarkalske tolkningstradition har udviklet sig, til tider $\mathrm{i}$ en slags feministisk retning, men oftest $\mathrm{i}$ androcentrisk retning. Vigtigt er, at den ikke har været essentialistisk den samme til alle tider. Dels må feministteologien påvise det betimelige i at "inkulturere" kvinder i kirken og acceptere dem som en fuldgyldig del af menneskeheden og kristenheden. Den anden store

5. Elizabeth Johnson. Quest for the Living God. Mapping Frontiers for the Living God. New York: Continuum 2007. Se i øvrigt: https://www.catholicnewsagency. com/news/23656/us-bishops-reaffirm-critique-of-controversial-theologians-work. (set 01.06. 2021).

6. Jamie L. Manson. 2014. "Feminism in faith: Sister Elizabeth Johnson's challenge to the Vatican." Interview med Elizabeth Johnson i buzzfeed.com. (set 01.06.2021). 
del af hendes forskning var at opspore en tidlig kristen her-story ${ }^{7}$ og derved gå bag om den binære diskussion om skrift og tradition. ${ }^{8}$

Hun rettede således skarp kritik mod tidligere og siddende paver, der på én gang hævder, at kvinder er ligestillede med mænd, og i virkeligheden, med Bonaventura, underordner kvinder under mænd både sociologisk og ekklesiologisk. ${ }^{9}$ Det gælder Paul VI's Inter insigniores fra 1977 mod ordination af kvinder og Johannes Paul II's Mulieris dignitatem fra 1988 om kvinders særlige kald til moderskabet. ${ }^{10}$ Børresen er ikke mindst opmærksom på sidstnævntes Ordinatio sacerdotalis fra 1994, som "teo-ulogisk" opsiger Vaticanum II's universelle bestemmelse af imago Dei og ud fra et oldkirkeligt argument anakronistisk hævder, at Herren selv kun ville mænd som præster (sacerdotes), da Kristus ikke ville døbes af Maria, men af Johannes Døberen. ${ }^{11}$ For Børresen var det forhold, at kvinder er hindret i ligestilling og samme menneskerettigheder som mænd alene på grund af deres køn, den såkaldte impedimentum sexus, en kilde til stadig undren og kritisk granskning:

...it is a fundamental right for human beings to be attributed a fully Godlike humanity, equally able to mediate between the Godhead and humankind. Preserving the canonical impedimentum sexus of femaleness, the institutional Church decrees that God is impeded from calling women to the priesthood because of their Godgiven cultic deficiency. Since the $20^{\text {th }}$ century, such an attribution of androcentric incapability to the Godhead has become perfectly unconvincing (Børresen 2002, 302).

7. Begrebet her-story henter Børresen fra den kendte katolske, feministiske nytestamentler, der ligesom Børresen arbejder rekonstruktivt, Elisabeth Schüssler Fiorenza. In Memory of Her. A Feminist Theological Reconstruction of Christian Origins. New York: Crossroad 1983. Jævnfør med Rosemary Radford Ruether (1936-), der som Børresen anvender de- og rekonstruktive læsninger af patristikken og som Fiorenza arbejder med begrebet woman/women church, Ruether. Women-Church: Theology and Practice of Feminist Liturgical Communities. San Francisco: Harper \& Row 1985.

8. I festskriftet udgivet i anledning af Børresens 70-års-fødselsdag findes en smagsprøve på hendes forskningsområder: Norderval \& Ore 2002.

9. Børresen. "Religion Confronting Women's Human Rights: The Case of Roman Catholicism." I Norderval \& Ore 2002, 289-308.

10. Børresen. "The Ordination of Women: To Nurture Tradition by Continuing Inculturation.” Studia Theologica 46 (1992): 3-13 (8-9).

11. Se $\mathrm{fx}_{\mathrm{x}}$ Børresen. "Sexologie réligieuse et droits humains des femmes." Journal of the European Society of Women in Theological Research 14 (2006): 119-131, her 127. Bemærk i øvrigt, at føromtalte Catharina Halkes fik forbud mod at henvende sig til pave Johannes Paul II, da han besøgte Holland i 1985. 


\section{Tolkningen af gudbilledlighed}

Den helt store anstødssten for en egalitært indstillet feministisk teologi er den konservative og patriarkalske traditions tolkning af menneskets gudbilledlighed. I denne tradition lægges vægten nemlig ikke på skabelsen af mennesket ifølge Gen 1,26-28 som en enhed i sig selv, men på skabelsen af manden (som overordnet kvinden) ved kun at læse Gen 1, 26-27a i kombination med Gen 2,7 (og18-24) og 1 Kor 11,7. Man læser altså kun en torso af den første skabelsesberetning, Gen 1,26-28 (præsteteksten $\mathrm{P}$ ), som derpå kombineres med en torso af den anden skabelsesberetning, Gen 2,7; 18-24 (Jahvisten J), samt en løsrevet sætning fra 1 Kor 11.

Lad os derfor først repetere den fulde ordlyd i Gen 1,26-28, der ifølge endnu en rekonstruktivistisk feminist, gammeltestamentleren Phyllis Bird, skal læses og tolkes som en enhed: ${ }^{12}$

(26) Derpå sagde Gud: "Lad os danne mennesker [hebr.: adam] ${ }^{13} \mathrm{i}$ vort billede, så de ligner os, og lad dem herske over havets fisk og himlens fugle og kvæget og hele jorden [adamah] og alt, der kryber på jorden.

(27) Og Gud skabte mennesket [adam] i sit billede, i sit billede skabte Gud det, som mandlig og kvindelig skabte Gud dem. (28) Og Gud velsignede dem, og Gud sagde til dem: "Bliv frugtbare og mangfoldige og opfyld jorden og underlæg jer den, Og hersk over havets fisk og himlens fugle,

Samt enhver levende skabning, der kryber på jorden." ${ }^{.14}$

Det er først i det 20. århundrede, det skabelsesbestemte imago Dei, som den første skabelsesberetning fortæller om, ikke uden videre tilskrives den mandligt definerede del af menneskeheden, men også den kvindelige. Trods kendskab til moderne eksegese fastholder enkelte traditionsstrenge, især i den romersk-katolsk kirke og i de ortodokse

12. Phyllis A. Bird. "Sexual Differentiation and Divine Image in the Genesis Creation Texts." I Image of God and Gender Models in Judaeo-Christian Tradition, red. Kari Børresen. 1991a, 11-34. Oslo: Solum Forlag, 11.

13. Det hebraiske adam uden artikel betyder "jordvæsnet”, som er taget af adamah, jorden. Her opstår en vanskelighed i et moderne sprog som engelsk, hvor det frem til ca. 1980 var kutyme at bruge termen "man" om menneske frem for den inklusive term for menneske, "human being". Dette er ændret, men det er fortsat et problem. Også på dansk ser man undertiden termen "menneske" forvekslet med "mand" eller "han”, selvom termen "menneske” er fælleskøn/neutrum på dansk. På svensk er den femininum, "människan hun”, mens finsk ikke har kønsbøjning overhovedet.

14. Oversat efter Biblia Hebraicum samlæst med Phyllis Bird (Bird 1991, 13, og Flemming F. Hvidberg. Det Gamle Testamente. Autoriseret oversattelse af 1931, med tekstkritisk noteapparat. København: Det Danske Bibelselskab 1974, 2-3. 
kirker, samt i konservative protestantiske kirker, at kvinder ikke er skabt i Guds billede sådan som mænd. Derfor må kvinder være underordnet mænd både i samfund og kirke. Alligevel finder vi i løbet af teologihistorien feministiske teologer, navnlig blandt middelalderens cisterciensernonner som Beatrice af Nazareth og Helfta-nonnerne fra 13. århundrede. Disse nonner fokuserede kun på Gen. 1 og tvivlede ikke et øjeblik på, at de også var skabt efter Guds billede (imago Dei) og omfattet af frelsen. Det viser både deres billedsprog og deres brug af bibeltekster, som når fx Gertrud af Helfta omtaler sig som Guds adoptivdatter eller som den fortabte datter. ${ }^{15}$

Kari Børresen er med sit analytiske arbejde et fornemt eksempel på den feministiske forsknings de- og rekonstruktion af traditionel teologis lære om menneskets status som skabt i Guds billede (imago Dei). Børresen har selv beskrevet målet med sin forskning som det at illustrere "the gradual inclusion of women in fully human God-likeness, as realised by interpretation of Scripture through Christian tradition." 16 Således plæderede Børresen for fuld accept af, at kvinder og deres religiøsitet er lige så repræsentativ for gudsforestillinger som mænd. I Børresens vokabular betyder det, at den hidtidige androcentriske, eller i bedste fald kønsnegerende, teologiske lære må genfortolkes. Hendes vision var en frugtbar og sund lære (sana doctrina), hvor katolsk forståelse af, at både skrift og tradition er resultater af åndens stadige åbenbaring, forbindes med ortodoks forståelse af, at ånden også opererer direkte gennem menneskers historie. Dette er ifølge Børresen yderligere kombineret med et tredje element, nemlig ortodoks teologis theosis-lære baseret på Kristi inkarnatoriske og genrejste menneskelighed. På det grundlag mente hun, at man kan integrere nutidens feministiske og holistiske indsigter $\mathrm{i}$ en normativ teologi på lige fod med den maskulint dominerede tradition (Børresen 1991a, 10).

Kari Børresen begyndte dette arbejde allerede i 1960'erne med sin disputats om kvinders underordning og lighed hos Augustin og Thomas Aquinas. Disputatsen, der var skrevet på fransk, fik imidlertid

15. Se nærmere Else Marie Wiberg Pedersen. "The Incarnation of Beatrice of Nazareth's Theology." I New Trends in Feminine Spirituality: the Holy Women of Liège and Their Impact, red. Juliette Dor m.fl. 1999. 61-81. Turnhout: Brepols; Else Marie Wiberg Pedersen. "Gottesbild - Frauenbild - Selbstbild. Die Theologie Mechtilds von Hackeborn und Gertruds von Helfta." I Vor dir steht die leere Schale meiner Sehnsucht. Die Mystik der Frauen von Helfta, red. Michael Bangert \& Hildegund Keul. 1999. 48-68. Leipzig: Benno Verlag.

16. Se Børresen. "Introduction: Imago Dei as Inculturated Doctrine." I Børresen 1991a, 7. 
først et bredt publikum i den engelske udgave fra $1981 .{ }^{17}$ Hun har både i disputatsen og siden i artikler vist, hvordan den andromorfe forstålse af Gud afspejles i såvel skrift som skrifttolkning. I forlængelse af Jacob Jervells arbejde ${ }^{18}$ har hun påvist, at de antropomorfe kategorier i den fremherskende teologiske antropologi hovedsageligt gengives i andromorfe prædikater. I denne traditionskreds fremhæves især det gammeltestamentlige billede af Gud som konge, kriger, dommer og patriarkalsk husbond og den nytestamentlige fremstilling af Gud som Faderen, Kristus som sønnen og Herren. Parallelt med, at Gud udelukkende afbildes med mandlige egenskaber og prædikater, bliver alene manden fremhævet som gudbilledlig. Sagt med andre ord: når Gud gøres andromorf, gøres alene manden teomorf. ${ }^{19}$

Ifølge Børresen rummer traditionel kristen antropologi en tvetydighed, som kommer til udtryk i to kontrasterende læreprincipper. Dels princippet, at androcentrisk kønshierarki/kvinders underordning etableres allerede ved Guds skabelsesorden, dels det modsatte princip, at menneskelig ligeværdighed/kvinders lighed med mænd realiseres gennem Kristi frelsergerning. Denne asymmetri mellem kvinders skabelsesbestemte underordning og deres frelsesbaserede lighed "krænkes" ifølge Børresen af dem, hun kalder "feministiske" kirkefædre. I den kategori placerer hun Clemens af Alexandria (d. før 215) og Augustin af Hippo (d. 430), der på hver sin måde definerede imago Dei som en ulegemlig og ukønnet kvalitet, forbundet med menneskelig dyd og fornuft. Børresen argumenterer videre, at netop dette ukønnede privilegium i mandlig maskering (disguise) tillader, at kvinders frelsesbaserede Kristuslighed tilbagedateres til skabelsesordenen på en sådan måde, at det ikke berører deres gudgivne underordning qua kvinder. Her ligger en spaltning, som teologisk antropologi har opretholdt til dette århundrede, primært i ortodoks og katolsk teologi, men samme spaltning ses i dele af protestantisk teologisk antropologi.

Som nævnt er et vigtigt aspekt ved Børresens forskning at påvise, at traditionen ikke er homogen, men at den i al sin ambiguitet rummer skæve vinkler, selvmodsigelser og modstrømninger. Således finder hun indslag af "patristisk feminisme" i både oldkirkens og middel-

17. Børresen. Subordination et Équivalence. Nature et rôle de la femme d'aprés Augustin et Thomas d'Aquin. Oslo/Paris: Universitetsforlaget/Maison Mame 1968. På engelsk, Subordination and Equivalence. The Nature and Role of Woman in Augustine and Thomas Aquinas. Washington DC: University Press of America 1981.

18. Jacob Jervell. Imago Dei. Gen.1,26f. im Spätjudentum, in der Gnosis und in der paulinischen Briefen. Göttingen: Vandenhoeck \& Ruprecht 1960.

19. Børresen. "Male - female? A Critique of Traditional Christian Theology." Temenos 13-14 (1977-78): 31-42. 
alderens teologiske antropologi, der også har influeret renæssance, reformation og moderne tid. Disse indslag fra især patristisk eksegese har tre strategier for inklusion af kvinder:

1. Kønsdifferentieringen i Gen 1,27b ("som mand og kvinde skabte han dem”) adskilles fra den følgende frugtbarhedsvelsignelse i Gen 1,28 og kædes sammen med Adams (kollektivt forstået) skabelse i Guds billede i Gen 1,26-27a.

2. Kvinder inkluderes som underordnede $i$ en kombination af 1 Kor 11,7 (manden som Guds billede og afglans skal ikke dække sit hoved, mens kvinden som mandens afglans skal bære slør) med Gen 1,26-27a og Gen 2,7. Dette befæstes yderligere med Paulus' hævdelse af mandens teomorfe fortrin i 1 Kor 11,8 med henvisning til Gen 2,18.21-23 (kvinden skabes til mandens medhjælp).

3. Negationen af Gen 1,27b i Gal 3,28 ("her er ikke mand og kvinde, for I er alle én i Jesus Kristus") tolkes som inkluderende kvinder i stedet for at ophæve kvindelighed.

Disse tekstpassager har da også været de mest omdiskuterede i feministisk teologi.

\section{Analyse af Børresens metodiske greb}

Det er karakteristisk for Børresens metode, at den ikke er historisk-kontekstuel, hvad man sagtens kan kritisere den for. Men Børresen har indskrevet sig som idéhistoriker og anvendt en idéhistorisk metode, ikke en historisk-kontekstuel. Læg dertil, at Børresen med sin forskning og forskningsmetode så tydeligt indgår i en dialog med primært den romersk-katolske kirkes øverste kleresi, og subsidiært med den ortodokse kirke.

Børresens forskning sigter på en dialog med især den officielle, katolske kirke. Derfor kan man forklare hendes metode med, at hun går ind på den romersk-katolske kirkes præmisser og argumenterer uden hensyn til de valgte teksters og teologers kontekst. For de er jo hævet over historiens omskiftelighed ifølge Børresens magtfulde dialogpartner. Med den næsten erklærede hensigt at komme i tale med de officielle, kønshierarkiske kirker fremdrager hun præcis de tekststeder og den tradition, som disse påberåber sig i deres version af teologisk antropologi og ekklesiologi med henblik på at fastholde 
en patriarkalsk magtstruktur. I en direkte og tekstnær afdækning af den herskende traditions eksegese endevender Børresen den teologiske diskurs, der sin inkohærens og anakronisme til trods påberåbes som eviggyldige sandheder. For som den norske matriark yderligere belærer kleresiet/Vatikanet, mens hun fremholder en katolsk og ortodoks forståelse af traditio gennem sin "feministiske" Augustin: "Kirkefedre bør imiteres, ikke ved gentagelse av doktriner, men ved dynamisk, nyskabende skriftfortolkning" (Børresen 1985, 129). Her er måske forklaringen på, at hun aldrig officielt fik mundkurv på af nogen katolsk øvrighedsinstans.

Hendes idéhistoriske metode består først og fremmest i at typificere nogle af teologihistoriens mest centrale kvinder og mænd. Gennem en grundig tekstanalyse af disse skikkelsers originaltekster på såvel latin som græsk afkoder Børresen traditionen for dens androcentrisme/feminisme, samt for graden af disse -ismer. Med sine typologiske detailanalyser peger Børresen på, hvor uholdbart og inkonsistent patriarkatet $\mathrm{i}$ virkeligheden er. I lighed med flere andre katolske feministteologer, bl.a. ovenfor nævnte Fiorenza og Ruether, er et hovedargument hos Børresen, at da vi nu lever i en moderne og post-patriarkalsk kultur, så fordres en ganske anden diskurs af kirkerne, hvis de for alvor vil i tale med hele kirkens menighed. Det er en diskurs, der tager sigte på et holistisk imago Dei, hvor kvinder og mænd er gudbilledlige qua kvinder og mænd i dette liv, og ikke først i et abstrakt futurum. Det er her indsatsen er væsentlig, konkluderer Børresen, ikke i en dybt forældet Maria-figur i form af Den ny Eva (også tolket som kirken), sådan som både den katolske og de ortodokse kirker gør for at legitimere en androcentrisk magtstruktur i kirken.

Kirkerne skulle i stedet lade sig inspirere af Augustins feministiske hensigter med henblik på at reformere det teologiske sprog og dermed rekonstruere en sund lære, der peger fremad: "When invoked to legitimate ecclesiastical power structures, the obsolete new Eve becomes perfectly noxious. Augustine's 'feminist' intent can inspire the necessary reformation of Christian God-language, in order to reconstruct a viable sana doctrina." (Børresen 1991b, 205). ${ }^{20}$

I det følgende vil jeg give eksempler på Børresens typologiske metode inden for gudbilledlighed. Hun har er helt spektrum af typologier, fra den aseksuelle gudbilledligheds typologi over "feministisk" gudbilledlighed til den kristocentriske typologi; og hun analyserer

20. Jf. Børresen, Kari E. "Interaksjon mellom skriftgrunnlag og senantik antropologi: Kirkefedres tolkning af 1 Mos. 1,27 og 1 Kor. 11,7." I Idekonfrontation under senantiken, red. Torben Christensen m.fl. 1985. 117-132. København: Platonselskabet, 128f. og Børresen. "In defense of Augustine: how femina is homo." Collectanea Augustina (1990): 411- 428. 
sig frem til, at både den aseksuelle og den kristocentriske er så forældede, at deres stadige forekomst i de udtalt patriarkalske kirker er en anakronisme, som de ikke bør fastholde.

Børresens typologiske afkodning af patristikken er kompliceret, og derfor vil jeg her bidrage med en analytisk redegørelse for den for dermed at give et indblik i, hvordan hun arbejder metodisk.

\section{Eksempel på Børresens afkodning af patristiske tolkninger af gudbilledlighed}

I sin idéhistoriske analyse af gudbilledlighed i relation til køn har Børresen udarbejdet en systematisk typisering af de forskellige patristiske tolkninger. ${ }^{21}$ Her tager hun afsæt i det, hun benævner "androcentrisk Kristuslighed", og som hun ser udtrykt hos Paulus i Ef 4,13: "indtil vi alle når frem til enhed i troen og i erkendelsen af Guds søn og bliver fuldkommen mand (eis andra teleion) af en vækst, der kan rumme Kristi fylde." 22 Dermed kan kvinder kun opnå frelsen ved at gøre sig mandlige, altså ved at antage Kristuslignende mandlighed.

\section{Kristocentrisk gudbilledlighed}

Herfra går Børresen videre til den tolkningsmodel, som hun typiserer "kristocentrisk typologi". Denne typologi karakteriseres ved, at den første mand, Adam, ved hjælp af en samlæsning af Gen 1,26-27a og Gen 2,7 defineres som gudbilledlig prototype. Derimod forbindes Evas skabelse (Gen 2,18.21-23) ikke med det teomorfe privilegium, men med frugtbarhedsvelsignelsen (Gen 1,28). Disse skriftsteder kobles yderligere sammen med Adam-Kristus-typologien (Rom 5,14) og den tilsvarende brudesymbolik af Kristus-kirken (Ef 5,32/2 Kor. 11,2), der i perioden 2.-4. århundrede udbygges til typologien $\mathrm{Ny}$ Adam - Ny Eva. Dermed transponeres det skabelsesbaserede kønshierarki til frelsesordenen: Eva fremstilles som den fra, efter og for

21. Børresen. “God's Image, Man's Image? Patristic Interprettaion of Gen. 1,27 and 1 Cor. 11,7.” I Børresen 1991b, 188-207. Grundlag for den følgende redegørelse er sidstnævnte artikel sammen med Børresen 1985. Dog følges typiseringen i Børresen 1991b, 188-207, som er hendes mest elaborerede analyse af imago Dei-tolkninger. I stedet for hele tiden at henvise til de to artikler af Børresen, henvises der til kildeteksterne, som Børresen behandler.

22. I den græske tekst i Nestlé-Aland står der mand (aner) og ikke menneske (anthropos), sådan som $\mathrm{fx}$ den nye danske oversættelse $\mathrm{i}$ en helt korrekt moderne tilpasning videregiver teksten. Heller ikke tekstapparatet nævner et ms. med varianten anthropos. 
Adam skabte kvinde, altså skabelsesmæssigt underordnet; hun er også typos for den i frelsesordenen inferiøre kvindelighed og billedet på menneskelig afhængighed af guddommelig almagt. Det er heri, Børresen ser kvinders underordnede status udbygget som en decideret udgrænsning af kvinder fra det guddommelige privilegium, nu alene tilskrevet mænd.

Det mest udtalte eksempel på denne tolkningsmodel finder Børresen hos Tertullian (d. ca. 225), der ikke nøjes med at frakende kvinder gudbilledlighed, men tillige giver kvinden alene-skylden for Adams fald (Gen 3,16): "Du er djævelens dør. Du plukkede frugten af det forbudne træ og fraveg først guddommelig lov. Du er den, der overtalte ham, som djævelen ikke er stærk nok til at angribe. Alt for let ødelagde du Guds billede, mennesket." 23

Tertullians kristocentriske typologi strækker sig fra skabelsen over den første synd og frem til frelsesordenen, hvor de genrejste kvinder transformeres til en blanding af engel og mand. ${ }^{24} \mathrm{Ud}$ over de nævnte typologier: Adam-Kristus (manden som gudsbilledets prototype), $\mathrm{Ny}$ Adam-Ny Eva (Kristi og mandens overordnede status i forhold til kirken og kvinden) finder man hos Tertullian også identifikationen af Ny Eva-kirken (ecclesia). ${ }^{25}$ Tertullians tolkning af vandet og blodet $\mathrm{i}$ Joh 19,34 som kirken, Den ny Eva, der er de levendes moder gennem dåb og nadver, bliver standardtolkning i patristisk ekklesiologi.

Mere uskyldig finder Børresen Justins (d. ca.165) og Irenæus' (d. ca. 200) tolkninger af gudsbilledet, som benævnes "androcentric innocence". Deres Eva-Mariatypologi, hvor Evas instrumentale rolle ved syndefaldet stilles op mod Marias instrumentale rolle ved frelsen, ser Børresen som en recapitulatio af den underordnede Eva. ${ }^{26}$

\section{Mandlig gudbilledlighed}

En tredje tolkningsmodel definerer Børresen som "mandlig gudbilledlighed". Her fremhæves Ambrosiaster, den uidentificerede forfatter til en række kommentarer til det paulinske tekstkorpus fra ca.

23. Tertullian, De cultu feminarum 1,1,2: "Tu es diaboli inanua; tu es arboris illius resignatrix; tu es divinae legis prima desertrix; tu es quae eum suasisti, quem diabolus aggredi non valuit; tu imaginem Dei, hominem, tam facile elisti." (CCSL 1,343). Min oversættelse.

24. Tertullian, ibid. 1,2,5: "Nam et uobis eadem tune substantia angelica re promisa, idem sexus qui et uiris, eamdem iudicandi dignationem pollicetur. " (CCSL 1,346).

25. Tertullian i hhv. De carne Christi 17,3-5 (CCSL 2,904-905) og De anima 43,10 (CCSL 2,847).

26. Justin, Dialogus 100,5. Jf. Irenæus, Adversus Haereses 5,19,1 (SC 153, 248250). 
370-380. Med en "antifeministisk" brod understreger kommentarerne kvinders mangel på medskabt gudbilledlighed ved at koble 1 Kor 11,7 med Gen 1,26-27a og Gen 2,7. I Ambrosiasters bog om Gammel og Ny Testamente (Liber quaestionum veteris et novi testamenti) defineres mænd éntydigt som teomorfe og Gud tilsvarende andromorft. Ambrosiaster læser skabelsesberetningen som et vidnesbyrd om monoteisme og monogeisme: én Gud har skabt ét menneske (unus unum fecit), og hele menneskeheden stammer fra denne ene (ab uno homine omne genus humanum). I en sammenlæsning af Gen 1,26-27a og 1 Kor 11,7a identificeres det teomorfe menneske (homo) med Paulus' mand (vir). Det understreges ligeledes, at kvinden (mulier) må bære slør, fordi hun ikke er Guds billede (quia non est imago dei). ${ }^{27} \mathrm{I}$ denne læsning ignoreres Gen 1,28’s tilkendelse af herredømme (dominatio) over dyrene til begge $\mathrm{k} ø$, mens mænd eksklusivt tilkendes ejendomsret (dominium) over kvinder, og kvinders underordning legitimeres både i teologisk og sociologisk forstand. ${ }^{28} \mathrm{I}$ kommentarerne til 1 Kor 11,7 og 14,34 skærpes kvinders underordning som underkastelse under mandens overherredømme (imperium), hvilket hævdes at være en naturlov (lex naturae) generelt og ekklesiologisk. ${ }^{29}$

Med Ambrosiaster har misogyn patristik nået sit højdepunkt, men ikke sin afslutning. Ambrosiaster får stor betydning i middelalderens katolske teologi. Den anonymt forfattede tolkningsmodel (fejlagtigt tilskrevet Ambrosius og Augustin) spiller en nøglerolle i middelalderens kanoniske ret, Corpus Iuris Canonici, og i den pønitenselitteratur især dominikanerne udvikler i senmiddelalderen. Samme argumentation findes i græsk teologi, for eksempel hos Johannes Chrysostomos (d. 407), dog med et lidt andet fokus. ${ }^{30}$ Da modellens eksplicitte eksklusion af kvindens gudbilledlighed og fuldstændige underordning af kvinder har store konsekvenser for kvinders status kirkeligt

27. Ambrosiaster, Liber quaestionum veteris et novi testamenti 21 (CSEL 50, 4748).

28. Ambrosiaster, ibid. 45,2-3: "cum non solum viro, sed et mulieri ista cernantur subiecta, quam constat dei imaginem non habere ... si imaginem dei homo in dominatione habet, et mulieri datur, ut et ipsa imago dei sit, quod absurdum est ... quam constat domino viri subiectam et nullam autoritatem habere?" (CSEL 50, 82-83).

29. Ad Corinthios prima 11,7-10 (CSEL 81,2,121-123) og Ad Corinthios prima 14,34: "si enim imago dei vir est, non femina, et viro subiecta est lege naturae quanto magis in ecclesia debent esse subiecta propter reverentiam eius, qui illius legatus est, qui etiam viri caput est." (CSEL 81,2,163).

30. Børresen 1991b, 194. nævner antiokenerne Diodorus af Tarsus (d. før 394) og Johannes Chrysostomos, hos hvem mænds herredømme over hele skaberværket, kvinder inklusive, betragtes som guddommeligt bestemt. Jf. Elisabeth Clark. Women in the Early Church. Message of the Fathers of the Church. Collegeville, Minn.: The Liturgical Press, 1983, 27-76. 
og samfundsmæssigt (teologisk, ekklesiologisk, ontologisk og sociologisk), er Børresens analyser af største betydning.

\section{Ambivalens om kvinders gudbilledlighed}

Efter disse negative tolkninger af kvinders gudbilledlighed gør Børresen rede for en række mere positive tolkninger, der dog ikke kan betragtes som ophævelser af de negative. Snarere er de udtryk for den ambivalens over for kvinder, som præger hovedparten af den skrifttolkning, der blev dominerende i kristen tradition. Udgangspunktet for de mere positive tolkningsmodeller finder Børresen som nævnt hos Clemens af Alexandria. Hun mener, at Clemens med værket Paidagogos er den første kirkefader, der forbinder kønsdifferentieringen i Gen 1,27b med den teomorfe, maskuline prototype i Gen 1,26-27a, samt med Gal 3,28, her tolket som kristomorf ikke-kønnethed. Herved lykkes det Clemens at anticipere kvinders frelsesbaserede gudbilledlighed i skabelsen, fordi gudbilledligheden i hans model er forbundet med ukønnet moral og fornuft. Den græske term for menneske (anthropos) inkluderer hos Clemens begge køn. I hans tolkning leder Kristus i sin rolle som Logos Paidagogos begge køn frem mod frelsen. I sin antropologi understreger Clemens, at "mænd og kvinder har lige del i fuldkommenhed og skal modtage den samme vejledning og disciplin". For navnet "menneskelighed" er fælles for mænd og kvinder, og for os "er der hverken mandligt eller kvindeligt i Kristus". ${ }^{31}$ Mens dette bygger på Gal 3,28, så fastslår Clemens med henvisning til Luk 20,34-35, at der dog i denne verden er forskel på kvinder og mænd.

I et andet af sine berømte værker, Stromata, gentager Clemens sin opfattelse af inklusiv skabelsesbestemt gudbilledlighed: en ulegemlig og åndelig skabning $($ Gen 1,26) såvel som kønnenes lige mulighed for frelse i Kristus (Kol 3,11; Gal 3,28). Alligevel, trods den skabelsesbaserede og moralske lighed, som han finder i Bibelen, fastholder Clemens, inspireret af stoisk og nyplatonsk filosofi, en biologisk og social ulighed. Således anlægger han i sidste instans et androcentrisk perspektiv, hvorved kvinden kun i sin rationelle sjæl har del i mandens åndelige og moralske natur, mens hun adskiller sig fra den eksemplariske mandlighed qua sin kvindekrop og kønsfunktion som kvinde (gyné). Ligeledes fastholder Clemens med basis i 1 Kor 11,3 og 11,8 et kønshierarki, der modsvarer forholdet Kristus/mand (aner), og som begrundes i Evas skabelse fra Adams ribben. Den mandlige prioritet til trods har kvinden dog den mulighed at imitere mandens moralske overlegenhed ved at tæmme sin inferiøre legemlighed. Clemens op-

31. Clemens, Paidagogos 1,410, 1-11, 1 (SC 70,128). 
fordrer derfor kvinder til at hengive sig til philosophia ligesom mænd..$^{32}$ Imidlertid inddrager Clemens ofte moralsk og fornuftsbaseret fuldkommenhed i sin tolkning af Ef 4,13, og han bevæger sig da fra en ukønnet gudbilledlighed i skabelsen til en mandlig gudbilledlighed i frelsen. For når frelse betyder at blive lig Kristus, den fuldkomne mand, må kvindelig lyst efter Clemens' logik bekæmpes med stoisk apatheia. ${ }^{33}$

\section{Symbolsk gudbilledlighed}

Under overskriften "symbolsk gudbilledlighed" har Børresen placeret blandt andre kirkefædrene Origenes (d. ca. 254) og Basilius d. Store (d. 379). Hun fremhæver Origenes for i et inklusivt sprog at definere gudbilledlighed som menneskets åndelige og ulegemlige skabelse. Gen 1,26-27a tolkes som det indre menneske (homo interior), mens Gen 1,27b's mand og kvinde tolkes som ånd og sjæl (spiritus et anima). ${ }^{34}$ Denne symbolske tolkning af inklusiv gudbilledlighed gentages med emfase af Basilius, der taler mod kvindelig svaghed. Anden har nemlig kraft, og kun legemet er svagt. ${ }^{35}$

\section{Preseksuel gudbilledlighed}

Den sjette typisering kalder Børresen "præseksuel gudbilledlighed” en type, der med oprindelse hos Gregor af Nyssa (d. ca. 395) især finder fodfæste i ortodoks teologi. Gregor inddelte skabelsen i to faser, hvoraf den første (Gen 1, 26 -27a) blev betragtet som en enkratistisk protologi, hvor kun mennesket skabt i Guds billede er åndeligt. I den præseksuelle åndelighed skal mennesket genrejses. Først i skabelsens anden fase (Gen 1,27b-28 koblet med Gen 2,7.18.21-23) skabes de to køn legemligt. Denne anden fase er ifølge Gregor begrundet i Guds forudviden (praescientia) om menneskets første synd - $\mathrm{i}$ analogi med græsk teologis lære om, at menneskets formering modsvares af dets dødelighed. ${ }^{36}$

32. Clemens, Stromata 4,8,58,2-60,4 (GCS 15,275-276) og ibid. 4,8,62,4-63,5 (GCS 15,277).

33. Ibid. 7,14,84,2 (GCS 17,60). Clemens udtrykker sig mindre androcentrisk, da han mod gnostikerne forsvarer menneskets formering. På grundlag af hele passagen, Gen 1,26-28, argumenterer han for, at formeringen er guddommelig som skabelse og inkluderer begge køn: "Mennesket [anthropos] er Guds billede, fordi det via sin menneskelighed samarbejder i fødslen af et andet menneske." Paidagogos 2,10,83,2 (SC 108,164).

34. Origenes, In Genesim homilia 1,13,15 (GCS 29,15,19).

35. Basilius, De creatione hominis sermo 1,18 (SC 160,212-216).

36. Gregor af Nyssa, De hominis opificio 16-18,22 (PG 44,177-194 and 204-205). 
Igen kommer ambivalensen dog til syne. For ganske vist er Gregor med Børresens ord "feminist", idet han placerer mand og kvinde på samme sekundære niveau i skabelsen - hvilket han gør ved at anføre Gal 3,28 (og omvendt udelade 1 Kor 11,7!) som bevis på sin lære om aseksuel gudbilledlighed i såvel skabelse som fuldendelse. Imidlertid ses det androcentriske perspektiv i hans lovprisning af enkratistisk jomfruelighed som den aseksuelle dyd, der kun opnås gennem mandlig overvindelse af kødets lyst. ${ }^{37}$ Men i hovedsagen er Gregors gudsbegreb metaseksuelt (jf. Gal 3,28), og at kønsdefinere Gud som far eller mor er for ham lige upassende. ${ }^{38}$

\section{Gudbilledlige kvinder}

Den sidste patristiske tolkningsmodel, Børresen opstiller i sin elaborerede typisering, benævner hun "gudbilledlige kvinder". Det er her, hun med Augustin mener at finde kulminationen på patristisk "feminisme" i form af en holistisk definition af både mandlighed og kvindelighed som egentlig menneskelig. Der er derfor stor sympati at spore i Børresens redegørelse for Augustins tolkninger af kvinders gudbilledlighed. Netop i denne sammenhæng bliver vi mindet om den vanskelige opgave, det var at sammenholde de to skabelsesberetninger i tiden, før Henning Bernhard Witter i 1711 fremsatte sin tese om to forskellige kilder (henholdsvis den præstelige og den jahvistiske) til to forskellige skabelsesfortællinger. Vi bliver også mindet om, at Augustins anliggende var apologetisk, vendt mod manikæisk dualisme og gnosticisme. ${ }^{39}$ Kontekstualiseringer af denne art er altid værdifulde for forståelsen af teksters anliggende og udsagnskraft; og man kan så mod Børresen indvende, at de øvrige kirkefædre $\mathrm{i}$ hendes behandling savner en lignende kontekstualisering.

Hvad Augustin angår, tager Børresen udgangspunkt i hans bogstavelige læsning af skabelsen, De Genesi ad litteram, hvor det er intentionen at kombinere de to skabelsesfortællinger. For at gøre dette skelner Augustin mellem to skabelsesmodi. Først den øjeblikkelige informatio (Gen 1), hvor Gud skaber de åndelige væsener (engle og de menneskelige sjæle, samt Adams og Evas legemer) som fornuftskim (rationes seminales). Dernæst en conformatio (Gen 2), hvor fornuftskimene aktualiseres i tid. I Børresens læsning lykkes det derved Augustin at kombinere den i Gen 1,27b-28 forekommende køns-

37. Gregor af Nyssa, De virginitate 20,4 (SC 178,172-174).

38. Gregor af Nyssa, Commentarius in canticum canticorum oratio 7 (Opera 6,212-213).

39. Børresen 1991b, 199. Gnosticisme er en bred term, som der i dag er delte meninger om blandt forskere i navnlig patristik. 
differentiering i mandligt og kvindeligt med prototypen menneske (homo), fremstillet i den forudgående passage, Gen 1,26-27a. Heri ser Børresen dog en "logisk inkohærens". Fordi Augustin lader sin bestræbelse på en holistisk antropologi (ved at tilbagevise en dual skabelse) hæmme af nyplatonsk åndelighed, tiltræder han de facto en aseksuel gudbilledlighed. Gudbilledligheden begrænses altså til det indre menneske, mens homo er skabt som en helhed af sjæl og legeme.

Det er Børresens pointe, at Augustin som den første går frontalt imod Paulus' benægtelse af kvindens gudbilledlighed i 1 Kor 11,7. I den forbindelse demonstrerer hun, hvordan Augustin tolker Paulus allegorisk for at forbinde hans forståelse af mandens eksklusive gudbilledlighed med den inklusive gudbilledlighed i Gen 1,26-27b. Løsningen er ganske kompleks: Augustin vælger i lighed med græsk antropologi at opdele det indre menneske (homo interior) i en højere og lavere del, men applicerer så disse to dele på kønsparret mand (vir) og kvinde (mulier) i 1 Kor 11,7 (og ikke som grækerne på mandligt og kvindeligt i Gen 1,27b). Mandskroppen symboliserer den højere sjælefunktion rettet mod de evige sandheder, mens kvindekroppen symboliserer den lavere sjælefunktion rettet mod de timelige ting. Der forudsættes hos Augustin en konflikt eller spaltning mellem køn og gudbilledlighed, som kun har med kvindens krop at gøre, for qua homo har hun del i både en højere og en lavere fornuftssjæl. Som grundlag for denne tolkning påberåber Augustin sig, ganske interessant, Gal 3,28, hvis ordlyd for ham understreger, at Kristi frelsesværk også genopretter kvindens åndelige gudbilledlighed, da hendes sjæl er skabt i informatio-fasen. Børresen pointerer, at Augustin med denne manøvre tilbagedaterer kvindens frelsesbaserede gudbilledlighed til skabelsen. ${ }^{40}$

I det berømte værk om Treenigheden, De Trinitate, er det Augustins hensigt at finde analogier til treenigheden i den menneskelige sjæl - som et bevis på Guds trinitariske karakter i mennesket fra skabelsen. Også her tager han afsæt i den antagelse, at Guds billede kan findes i den menneskelige sjæl, der er åndelig og aseksuel, og derfor fælles for mand (vir) og kvinde (mulier) som menneske (homo). Men i dette værk eksponeres spaltningen mellem kvinders gudbilledlige homo interior og deres i relation til manden underordnede homo exterior. For at forklare ordlyden i 1 Kor 11,7 deler Augustin endvidere

40. De Genesi ad litteram 3,22: "tamen et femina, quia corpore femina est, renovatur etiam ipsa in spiritu mentis suae in agnitionem dei secuncum imaginem eius, qui creavit non est masculuus et femina, sicut enim ab hac gratia renovationis et reformatione imaginis dei non separantur feminae, quamuis in sexu corporis earum aliud figuratum sit, secundum quod vir solus dicitur esse imago et gloria dei..." (CSEL 28,1, 88-90). 
fornuftssjælen op i en overordnet og en underordnet del (ratio superior et ratio inferior), symboliseret ved henholdsvis "det mandlige" og "det kvindelige". Han baserer sin allegoriske eksegese på en a priori antagelse af Evas underordning under Adam (Gen 2,18-24). Augustin hævder så, at kun den overordnede del af den menneskelige fornuftssjæl er skabt i Guds billede, sådan at manden (vir) er imago Dei, mens kvinden (mulier) ikke er det. Kvinden kan ganske enkelt ikke qua kvinde symbolisere imago Dei. Men da manden og kvinden tilsammen har den menneskelige fornuftssiæls entitet, implicerer det, at kvinden qua menneske (homo) er skabt i Guds billede. Der er således en modstrid mellem kvindens gudbilledlige menneskelighed og hendes ikke-gudbilledlige kvindelighed, mellem hendes aseksuelle sjæl og hendes kønnede kvindekrop. Med emfase på Gen 2,18ff. (snarere end på Gen 1,26-27) tolkes derfor kun Adam teomorft:

Løsningen ligger, tror jeg, i hvad jeg allerede har sagt, da jeg diskutere-
de det menneskelige sinds natur, nemlig at kvinden sammen med sin
mand er Guds billede, sådan at hele substansen er ét billede. Men når
hun kaldes medhjælp, en funktion, der alene tilskrives hende, så er hun
ikke Guds billede. Men hvad manden angår, er han alene Guds billede
lige så fuldt og helt, som når han og kvinden er forenet i én. ${ }^{41}$

Børresen påviser videre, at den lighed, Augustin etablerer på skabelsesplanet og frelsesplanet ved at kombinere informatio og conformatio, ikke gælder på det ontologiske plan. I en kommentar til Gal 3,28 understreger Augustin, at den lighed i frelsen, der opnås i troen på Kristus, ikke har at gøre med dette liv. ${ }^{42} \mathrm{Han}$ betragter således kvinders underordning som gudgiven i skabelsen og som en naturlig orden (ordo naturalis). Ligeledes hævder han, at skabelsen af feminal mulier som mandens medhjælp (Gen 2,18) alene skyldes kvindens underordnede og passivt-receptive rolle i forplantningen. ${ }^{43}$

Man kan spørge, om Børresen er alt for positiv over for Augustin som feminist? Denne Augustin-fortolkning bliver jo hendes primære skyts mod den etablerede katolske kirkes påstand om en inhærent og uforanderlig patriarkalsk kristendom. Først i analysen af De ci-

41. Augustin, De Trinitate 12,7,10: "credo, illud esse quod iam dixi euro de natura humanae mentis agerem, mulierem euro viro suo esse imaginem dei ut una imago sit tota illa substantia; euro autem ad adiutorium distribuitur, quod ad eam ipsam solam attinet non est imago dei; quod autem ad virum solum attinet imago dei est tam plena atque integra quam in unum coniuncta muliere." (CCSL 50,364-365). Min oversættelse.

42. Augustin, Epistulae ad Galatas Expositio 3,28 (CSEL 84,92-93).

43. Augustin, De civitate Dei 19,15 (CCSL 48,682-683); Quaestiones Genesis 153 (CCSL 33,59) og De Genesi ad litteram 9,5 (CSEL 28,1,273). 
vitate Dei afslører hun endelig Augustins "feminisme" som androcentrisk, hvad forståelsen af frelsesordenen angår. Som "feminist" fastslår Augustin nemlig i konsekvens af den inklusive conformatio, at kvinden vil opstå som kvinde, men med et androcentrisk perspektiv i aseksuel skikkelse. For i opstandelsen er der hverken samleje, børnefødsler eller ægteskab. ${ }^{44}$ For yderligere at begrunde kvinders genrejsning indføjer Augustin så de kendte kristocentriske typologier, baseret på en sammenkobling af Gen 2,21-22, Efes 5,32 og Joh 19,34, sådan at Evas dannelse fra Adams side præfigurerer kirkens og Kristi enhed. Foruden denne Eva-kirke-typologi anfører Augustin Eva-Maria-typologien, hvor Evas instrumentale rolle i synden (som i øvrigt helt er Adams ansvar) modsvares af Marias instrumentale rolle i frelsen. ${ }^{45}$ Alligevel bliver kvinden den skabelsesbestemt underordnede, fordi Augustin qua sit androcentriske perspektiv fremhæver manden som det mere ærefulde køn (sexus honorabilior). ${ }^{46}$

\section{Kvinden er en defekt mand}

Børresen demonstrerer videre, hvordan den augustinske imago Dei-forståelse blev adopteret af den skolastiske teologi. Den androcentriske typologi forstærkes hos bl.a. den franciskanske skolastiker, Bonaventura (d. 1274), i dennes sententiae, hvor manden også i ægteskabet repræsenterer Gud. ${ }^{47}$ Den udbygges yderligere hos den dominikanske skolastiker, Thomas Aquinas (d. 1274). Med næsten 900 års interval genopliver Thomas i Summa theologicas første del om skabelsen tolkningen af Gen 1,26f i perspektivet af 1 Kor 11,7, sådan at Adam tolkes som mand (ikke som jordvæsnet taget af jorden, $a d a-$ mah), og i den kapacitet får Adam prioritet som det eksemplariske menneske. Børresen påviser tillige, at Thomas går ud over den augustinske tolkning i sin androcentrisme, da han inddrager aristoteliske argumenter, både biologiske og sociologiske. Ved at koble Aristoteles' idé om kvinden som "defekt mand" med tolkningen af Eva som prototypen på kvinders svage natur (Gen 3) definerer Thomas kvinde-mennesket som en defekt, uudviklet mand. ${ }^{48}$ Dette får stor effekt for kvindebilledet i århundreder fremover.

44. Augustin, De civitate Dei 22,17 (CCSL 48,835-836).

45. Augustin, De agone christiano 22,24 (CSEL 41,124-125).

46. Augustin, De diversis quaestionibus 11 (CCSL 44 A,18): "Ergo quia virum oportebat suscipere, qui sexus honorabilior est."

47. Bonaventura, Commentaria in Quatuor Libros Sententiarum 4,16,2,2: "Unde etiam est in matrimonio, quod vir significat Deum, et mulier significat ecclesiam sive animam." Jf. Bonaventura, Ad Corinthios prima 11,7.

48. Thomas, Summa Theologiae 1,92,1. Jf. Thomas, De Genesi ad litteram 9, 5 og Summa Theologiae Supplementum 39. 


\section{Afsluttende bemærkninger: En moderne matristikers} post-patriarkalske fremtidsorientering

Gennem de viste typiseringer afdækker Børresen patristikkens og den senere teologiske diskurs om kvinder og gudbilledlighed. Hun påviser gennem sin typologiske analyse, at denne diskurs på ingen måde er éntydig, men tværtimod er præget af inkohærens og manglende logik. Den veksler mellem at være direkte anti-feministisk (som hos Tertullian og Ambrosiaster) og at være androcentrisk feministisk (som hos Clemens og Augustin). I Børresens analyseoversigt træder det tydeligt frem, at især tolkningen af 1 Kor 11,7 og Gal 3,28 har været signifikant for tolkningen af skabelsesberetningen og opfattelsen af kvindens gudbilledlighed eller mangel på samme. Omvendt kan man med lige så stor ret hævde, at det faktisk er den dominerende a priori opfattelse af kvinder som underordnede skabninger, der har været signifikant for tolkningen af teksterne. Men der er ikke nogen tvivl om, at Børresen i sin afdækning af patristikkens tolkning af disse centrale tekster for udviklingen af teologisk antropologi og ekklesiologi, herunder embedsteologi, har udført et meget vigtigt pionerarbejde.

Man kan naturligvis altid tage de negative briller på og fx anholde det faktum, at Børresen aldrig går ind i en nærmere diskussion af teksternes kontekst eller forfatternes forskellige "Sitz im Leben". Den kritik kan man dog afvise med, at Børresen arbejder idéhistorisk, ikke historisk-kontekstuelt. Mere præcist arbejder hun typologisk for at kunne de- og rekonstruere traditionen og påvise, at et patriarkalsk paradigme ikke er den indiskutable konstans, som de patriarkalske kirker - og med dem, bemærkelsesværdigt nok, de radikalfeministiske teologer med deres essentialistiske tolkninger - vil hævde. Tværtimod viser hendes dekonstruktive læsninger af især kirkens "store mænd", at der er ambivalens og forandring at finde i traditionen, ikke en essentiel konstans.

Men Børresen nøjedes ikke med et paradigme, hvis mål det er at dekonstruere den vedtagne læsning af kirkens "store mænd". Faktisk arbejdede hun ud fra endnu to paradigmer, der har rekonstruktionen som mål. I det ene af disse to rekonstruktive paradigmer søgte hun at opstille en matristik med henblik på at komplettere teologihistorien. ${ }^{49} \mathrm{I}$ det andet rekonstruktive paradigme søgte hun at finde frem

49. Se Børresen. "Matristics: Ancient and Medieval Church Mothers", i: Theologie zwischen Zeiten und Kontinenten. Für Elisabeth Gössmann, red. Theodor Schneider \& Helen Schüngel-Straumann. 1993. Freiburg: Herder, 64-83. Jf. her også bl.a. Ruether. 
til de gudsmodeller, ${ }^{50}$ der kan bidrage til det holistiske gudsbillede, som ifølge hende vil bidrage til at gøre kristendommen tidssvarende og kirkerne fremtidsorienterede. Børresen troede ikke på, at kvinder skulle finde gudindebilleder som fx Daly, men at de snarere skulle forske i et inklusivt teologisk sprog. Hun troede på, at det gennem en rekonstruktion af teologihistorien, med patristisk antropologi som bro, var muligt at skabe en teologi, der var en fuldstændig menneskelig diskurs om Gud, omfattende både kvinders og mænds religiøse erfaringer.

I en af sine sidste publikationer gjorde Børresen opmærksom på, at den katolske kirkes syn på kvinder ud over at være anakronistisk også var anti-økumenisk. Med beklagelse understregede hun, at mens de fleste lutherske kirker har et kønsneutralt præsteskab, så bevarer den stadigt gældende Codex Iuris Canonici 1983 et mandligt præsteskab, idet tidligere erklæringer gentages: "kun en døbt mand kan modtage gyldig ordination" (canon 1024). Hun påpegede dertil, at emnet endnu var så varmt under kommissionsarbejdet Lutheran-Roman Catholic Commission on Unity i 1995-2006, at det måtte udelukkes fra forhandlingerne, hvis Luthersk Verdensforbund skulle forfølge sin økumeniske dialog med Det Pavelige Råd til Fremme af Kristen Enhed. ${ }^{51}$ Man kan kun håbe, at Børresens arbejde for en opdatering af katolsk kirke og teologi vil føre til, at kvinder bliver opgraderet som ligestillede og ligeværdige med mænd og dermed opnår lighed både i kirke og samfund, samt at det økumeniske arbejde dermed kan omfatte hele menneskeheden, sådan som hun ønskede. Men med kønsdiskursen i pave Frans' klimarundbrev, Laudato si, fra 2015 og formaningstalen til Amazon-området, Querida Amazonia, fra 2020 som signifikante eksempler tyder intet på, at Børresens ønske for de ikke-protestantiske kirker bliver opfyldt snarligt.

50. Se Børresen, “God's Image, Man’s Image? Female Metaphors Describing God in the Christian Tradition." Temenos 19-20 (1983): 17-32.

51. Børresen. "Impedimentum Sexus. The Cultic Impediment of Female Humanity.” In Bodies, Borders, Believers, red. Anne Hege Grung m.fl. 2015. 243-268. Eugene, Or.: Pickwick, 244-245. Se også den posthumt udgivne artikel, som giver et skarpt analytisk blik på fastholdelsen af kvinders underordning fra pave Paul VI til pave Frans: Børresen. "Moderne maktkamp mellom pave og konsil." Teologisk Tidsskrift 2 (2016): 135-155. 


\section{Litteratur}

\section{Patristiske kilder}

Ambrosiaster. 1908. Pseudo-Augustin, Quaestiones veteris et novi testamenti. I Corpus scriptorum ecclesiasticorum latinorum (CSEL) 50, red. A. Souter Wien/Berlin: De Gruyter.

Augustin. 1955. De civitate Dei. I Corpus christianorum. Series Latina (CCSL) 48, red. B. Dombart. Turnhout: Brepols.

Augustin. 1894. De Genesi ad litteram. I CSEL 28.1, red. J. Zycha. Wien/ Berlin: De Gruyter.

Augustin. 2001 (1958) De Trinitate. I CCSL 50, red. W.J. Mountain. Turnhout: Brepols.

Augustin. 1971. Epistulae ad Galatas Expositio. I CSEL 84, red. J. Divjak. Berlin: De Gruyter.

Augustin. 1958. Quaestiones Genesis. I CCSL 33, red. D. De Bruyne. Turnhout: Brepols.

Basilius. 1970. De creatione hominis sermo. I Sources chrétiennes (SC) 160, red. A. Smets. Paris: Les Éditions du Cerf.

Bonaventura. 1885. Commentaria in Quatuor Libros Sententiarum Magistri Petri Lombardi 4.16.I Opera Omnia 1-4, red. Collegium S. Bonaventurae. Firenze: Quaracchi.

Clemens af Alexandria. 1939. Stromata. I Clemens Alexandrinus 2-3. Die Griechischen Christlichen Schriftsteller der ersten drei Jahrhunderte (GCS) 15, red. Otto Stählin. Berlin: De Gruyter.

Clemens af Alexandria. 1983 (1960). Paidagogos I. I SC 70, red. H.-I. Marrou. Paris: Les Éditions du Cerf.

Gregor af Nyssa. 1986 (1960). Commentarius in canticum canticorum oratio. Gregorii Nysseni Opera 6, red. Herman Langerbeck. Leiden: Brill.

Gregor af Nyssa. 1857-66. De opificio hominis. I Patrologia cursus completes. Series Graeca (PG) 44, red. J.P. Migne. Turnhout: Brepols.

Gregor af Nyssa. 1978. De virginitate. I SC 178, red. P. Maraval. Paris: Les Éditions du Cerf.

Justin. 1914. Dialogus 100. I Die ältesten Apologeten, red. Edgar J. Goodspeed. Göttingen: Vandenhoeck \& Ruprecht. 
Origenes. 2012 (1920). Homiliae in Genesim. I Origenes Werke 6. GCS 29, red. Wilhelm Adolf Baehrens. Berlin: De Gruyter.

Tertullian. 1996 (1954). De anima. I CCSL 2, red. J. H. Waschink. Turnhout: Brepols.

Tertullian. 1996 (1954). De carne Christi. I CCSL 2, red. A. Kroymann. Turnhout: Brepols.

Tertullian. 1954. De cultu feminarum. I CCSL 1, red. A. Kroymann. Turnhout: Brepols.

Thomas Aquinas. 2018. Summa Theologiae 1. I Latin-English Opera omnia, red. Laurence Shapcote. St. Paul: Emmaus Academic.

Thomas Aquinas. 2018. Summa Theologiae Supplementum 39. I Opera omnia, red. Laurence Shapcote. St. Paul: Emmaus Academic.

\section{Øvig litteratur}

Bird, Phyllis A. 1991. "Sexual Differentiation and Divine Image in the Genesis Creation Texts." I Image of God and Gender Models in Judaeo-Christian Tradition, red. Kari Børresen. 11-34. Oslo: Solum Forlag.

Børresen, Kari E. 1968. Subordination et Équivalence. Nature et rôle de la femme d'aprés Augustin et Thomas d'Aquin. Oslo/ Paris: Universitetsforlaget/Maison Mame.

Børresen, Kari E. 1977-78. "Male - female? A Critique of Traditional Christian Theology." Temenos 13-14: 31-42.

Børresen, Kari E. 1983. “God's Image, Man's Image? Female Metaphors Describing God in the Christian Tradition.” Temenos 19-20: 17-32.

Børresen, Kari E. 1985*. "Interaksjon mellom skriftgrunnlag og senantik antropologi: Kirkefedres tolkning af 1 Mos. 1,27 og 1 Kor. 11,7.” I Idekonfrontation under senantiken, red. Torben Christensen m.fl. 117-132. København: Platonselskabet.

Børresen, Kari E. 1990. "In defense of Augustine: how femina is homo." Collectanea Augustina : 411- 428.

Børresen, Kari E. 1991a. "Introduction: Imago Dei as Inculturated Doctrine." I Image of God and Gender Models in Judaeo-Christian Tradition, red. Kari Børresen. 7-10. Oslo: Solum Forlag.

Børresen, Kari E. 1991b*. “God’s Image, Man’s Image? Patristic Interpretation of Gen. 1,27 and 1 Cor. 11,7." I Image of God and Gender Models in Judaeo-Christian Tradition, red. Kari Børresen. 188-207. Oslo: Solum Forlag. 
Børresen, Kari E. 1992. "The Ordination of Women: To Nurture Tradition by Continuing Inculturation." Studia Theologica 46: 3-13.

Børresen, Kari E. 1993. "Matristics: Ancient and Medieval Church Mothers." I Theologie zwischen Zeiten und Kontinenten. Für Elisabeth Gössmann, red. Theodor Schneider \& Helen Schüngel-Straumann, 64-83. Freiburg: Herder.

Børresen, Kari E. 2002. From Patristics to Matristics. Selected Articles on Christian Gender Models by Kari Elisabeth Børresen, red. Øyvind Norderval \& Katrine Lund Ore. Rom: Herder.

Børresen, Kari E. 2002. “Religion Confronting Women’s Human Rights: The Case of Roman Catholicism." I From Patristics to Matristics. Selected Articles on Christian Gender Models by Kari Elisabeth Børresen, red. Øyvind Norderval \& Katrine Lund Ore. 289-308. Rom: Herder.

Børresen, Kari E. 2006. "Sexologie réligieuse et droits humains des femmes." Journal of the European Society of Women in Theological Research 14: 119-131.

Børresen, Kari E. 2015. "Impedimentum Sexus. The Cultic Impediment of Female Humanity." I Bodies, Borders, Believers, red. Anne Hege Grung m.fl. 243-268. Eugene, Or.: Pickwick.

Børresen, Kari E. 2016. "Moderne maktkamp mellom pave og konsil”. Teologisk Tidsskrift 2: 135-155.

Clark, Elisabeth. 1983. Women in the Early Church. Message of the Fathers of the Church. Collegeville, Minn.: The Liturgical Press.

Daly, Mary. 1973. Beyond God the Father. Toward a Philosophy of Women's Liberation. Boston: Beacon Press.

Fiorenza, Elisabeth Schüssler. 1983. In Memory of Her. A Feminist Theological Reconstruction of Christian Origins. New York: Crossroad.

Halkes, Catharina. 1982. Gott hat nicht nur starke Söhne. Grundzüge einer feministischen Theologie. Gütersloh: Mohn.

Hvidberg, Flemming F. 1974. Det Gamle Testamente. Autoriseret oversattelse af 1931, med tekstkritisk noteapparat. København: Det Danske Bibelselskab.

Jervell, Jacob. 1960. Imago Dei. Gen. 1,26f. im Spätjudentum, in der Gnosis und in der paulinischen Briefen. Göttingen: Vandenhoeck \& Ruprecht.

Johnson, Elizabeth. 2007. Quest for the Living God. Mapping Frontiers for the Living God. New York: Continuum. 
Manson, Jamie L. 2014. "Feminism in faith: Sister Elizabeth Johnson's challenge to the Vatican.” Interview med Elizabeth Johnson. I buzzfeed.com.

Norderval, Øyvind \& Katrine Lund Ore. 2002. "Introduction”. I From Patristics to Matristics. Selected Articles on Christian Gender Models by Kari Elisabeth Børresen, red. Øyvind Norderval \& Katrine Lund Ore. XVII-XX. Rom: Herder.

Pave Frans. 2015. https:/www.vatican.va/content/francesco/en/encyclicals/ documents/papa-francesco_20150524_enciclica-laudato-si.html

Pave Frans. 2020. https://www.vatican.va/content/francesco/en/apost_ exhortations/documents/papa-francesco_esortazione-ap_20200202_ querida-amazonia.html

Ruether, Rosemary Radford. 1985. Women-Church: Theology and Practice of Feminist Liturgical Communities. San Francisco: Harper \& Row.

Strøm, Anne-Lise OP. 2016. http://www.katolsk.no/nyheter/2016/04/ in-memoriam-kari-elisabeth-borresen

USA's bispekonference: https://www.catholicnewsagency.com/ news/23656/us-bishops-reaffirm-critique-of-controversial-theologians-work

Wiberg Pedersen, Else Marie. 1999. "The Incarnation of Beatrice of Nazareth's Theology." I New Trends in Feminine Spirituality: the Holy Women of Liège and Their Impact, red. Juliette Dor m.fl. 61-81. Turnhout: Brepols.

Wiberg Pedersen, Else Marie. 1999. "Gottesbild - Frauenbild - Selbstbild. Die Theologie Mechtilds von Hackeborn und Gertruds von Helfta." I Vor dir steht die leere Schale meiner Sehnsucht. Die Mystik der Frauen von Helfta, red. Michael Bangert \& Hildegund Keul. 48-68. Leipzig: Benno Verlag. 